\title{
Manfaat Bimbingan Kelompok Dalam Meningkatkan Etika Komunikasi Siswa
}

\author{
Enny Fitriani $^{1}$, Edi Zulfikar ${ }^{2}$
}

\author{
Jurusan Bimbingan Konseling, Universitas Muslim Nusantara Al Washliyah. \\ E-mail: ennyfitriani146@gmail.com, Telp: +6285262323418
}

\begin{abstract}
The technological advances that lead to the waning of eastern culture and the disintegration of the norms of politeness in every way, thus exert a bad influence on society, especially students, because adolescence is a transitional period of adolescent children making their emotions volatile or unstable. This is why teenagers are easily influenced in everything, so their ethics of communicating has faded. This research is to know the benefit of group guidance in improving student communication ethics, this research is categorized into pre experimental research (Pre-Experiment Design), with experimental design used in this research is The One Group Pratest Posttest. This study involves two types of variables. The free variables are Group Guidance, the dependent variable is the Ethics of Communicating. The instruments used in this study were the questionnaire of communication ethics as well as group guidance services and were analyzed using descriptive statistics.
\end{abstract}

Keywords: Group Guidance, Communication Ethics, Emotion

\begin{abstract}
Abstrak : Kemajuan teknologi yang menyebabkan memudarnya kebudayaan timur dan lunturnya norma-norma kesantunan dalam segala hal, sehingga memberikan pengaruh buruk bagi masyarakat, khususnya kaum pelajar, karena masa remaja merupakan masa transisi dari anak-anak keremaja membuat emosi mereka mudah berubah-ubah atau tidak stabil. Hal inilah yang menyebabkan para remaja mudah sekali terpengaruh dalam segala hal, sehingga etika berkomunikasi merekapun sudah memudar. Penelitian ini untuk mengetahui manfaat bimbingan kelompok dalam meningkatkan etika komunikasi siswa, penelitian ini dikategorikan ke dalam penelitian pra eksperimental (Pra -Experiment Design), dengan rancangan eksperimen yang digunakan dalam penelitian ini adalah The One Group Pratest Posttest. Penelitian ini melibatkan dua jenis variabel.Variabel bebas adalah Bimbingan Kelompok, variabel terikatnya adalah Etika Berkomunikasi. Instrumen yang digunakan dalam penelitian ini adalah tes angket etika komunikasi serta layanan bimbingan kelompok dan dianalisis dengan mengunakan statistik deskriptif.
\end{abstract}

Kata kunci: Bimbingan Kelompok, Etika Komunikasi, Emosi

\section{PENDAHULUAN}

Pada era Globalisasi di masa sekarang ini, arus informasi begitu deras masuk dari berbagai macam media, baik media Televisi, Media Masa dan Internet. Dimana semua manusia 
tanpa batas usia bebas mengaksesnya tanpa ada filternya. Apalagi dengan adanya internet arus informasi tersebut makin mudah diperoleh sehingga membuat cara pandang remaja kita sedikit demi sedikit berubah meninggalkan cara pandang leluhur kita sebagai orang timur. Hal tersebut memiliki dampak yang besar terhadap perkembangan perilaku siswa. Fenomena yang terjadi saat ini siswa yang seharusnya memempunyai perilaku positif karena mereka dalam proses pendidikan pembentukan karakter, tetapi seiringi dengan adanya pengaruh tayangan televisi, internet, majalah, gambar-gambar porno dan masih banyak lagi yang lain yang sangat mudah diakses oleh remaja, memberikan dampak negatif pada perilaku remaja. hal ini kalau dibiarkan terus menerus nantinya bisa merusak perkembangan generasi penerus bangsa.

Dampak negatif dari arus informasi yang bebas sudah bisa dirasakan pada perubahan perilaku siswa. Seringkali siswa melakukan perbuatan yang kadang-kadang tidak pantas dan kata-kata yang kurang sopan terhadap guru dan teman- temannya, melalui perilaku yang tidak mempunyai etika sopan santun dan dari tutur kata yang kurang pantas diucapkan oleh seorang siswa. Sopan santun adalah budi pekerti yg baik, tata karma, peradaban, kesusilaan (Kamus Besar Bahasa Indonesia). Etika komunikasi merupakan bagian dari salah satu sopan santun dan juga dapat diartikan sebagai suatu tingkah laku seseorang dalam kehidupan sehari-hari yang harus disesuaikan dengan kodratnya, tempat, waktu dan kondisi lingkungannya.

Ada banyak tuntutan di lingkungan sekolah maupun masyarakat. Diantaranya adalah etika. Dalam Kamus Besar Bahasa Indonesia edisi ke-1 (K. Bertens: 2013:4), Etika dijelaskan dengan membedakan tiga arti: "1) ilmu tentang apa yang baik dan apa yang buruk dan tentang hak dan kewajiban moral (akhlak); 2) kumpulan asas atau nilai yang berkenaan dengan akhlak; 3) nilai mengenai benar dan salah yang dianut suatu golongan atau masyarakat" Etika komunikasi merupakan suatu rangkuman istilah yang mempunyai pengertian tersendiri, yakni norma, nilai, atau ukuran tingkah laku yang baik dalam kegiatan komunikasi disuatu masyarakat. Pada dasarnya komunikasi interpersonal dapat berlangsung secara lisan maupun tertulis. Secara lisan dapat terjadi secara langsung (tatap muka), maupun dengan menggunakan media seperti telepon, SMS, facebook, e-mail, dan sebagainya, Suranto (2011: 135)

\section{METODE PENELITIAN}

Populasi dalam penelitian ini adalah seluruh siswa kelas VIII SMP Swasta Silinda yang terdiri 55 orang siswa. Sedang subjek dalam penelitian ini adalah 10 orang siswa yang ditentukan secara purposive sampling.

Penelitian ini dikategorikan ke dalam penelitian Pra-Experimental Designs. Peneliti sebelumnya memberikan pre-test kepada kelompok yang akan diberikan perlakukan. Kemudian peneliti melakukan perlakuan atau treatment berupa bimbingan kelompok. Setelah selesai perlakuan, peneliti memberikan post-test. Besarnya pengaruh perlakuan dapat diketahui secara lebih akurat dengan cara membandingkan antara hasil pre-test dengan post-test. Untuk memudahkan memahami paradigma penelitian ini dapat dilihat pada gambar di bawah ini:

\section{$\mathbf{O}_{1} \quad \mathbf{x} \mathbf{O}_{2}$}

\section{Keterangan:}

O1: Pra-test diberikan sebelum melakukan bimbingan kelompok

$\mathbf{X}$ : perlakuan (bimbingan kelompok)

$\mathbf{O}_{2}$ :Post-test diberikan setelah melakukan bimbingan kelompok. 
Pelaku tindakan dalam penelitian ini adalah peneliti. Adapun kegiatan yang dilakukan peneliti adalah :

1. Melakukan pre-test dengan memberikan angket

2. Membuat Enam (6) Rencana Pelaksanaan Layanan

3. Melakukan (treatment) bimbingan kelompok selama enam kali pertemuan dengan topik bahasan yang berbeda.

4. Melakukan post-test dengan cara membagikan angket yang sama.

Untuk lebih jelasnya peneliti memberikan bagan desain penelitian yaitu pre experimenral pre test dan post tes group

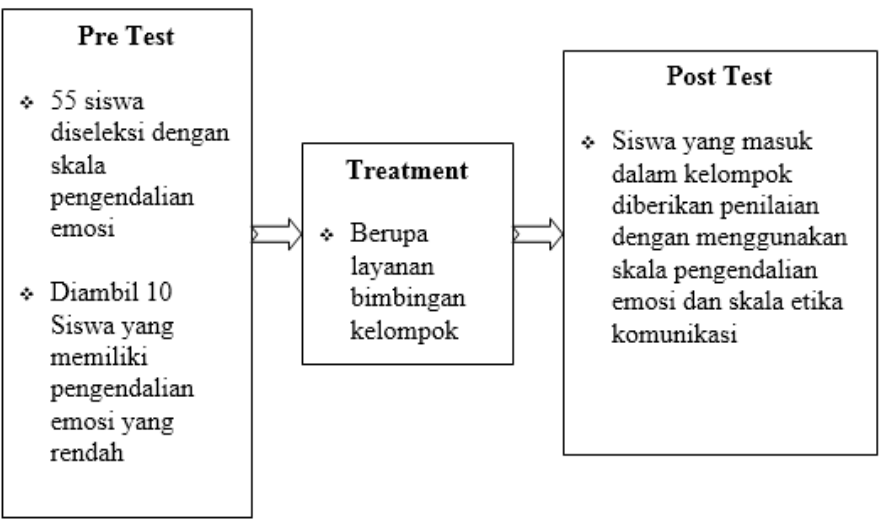

Pengumpulan data dilakukan melalui angket yang diberikan kepada siswa. Arikunto (2006:151) mengatakan bahwa "skala atau kuesioner adalah sejumlah pernyataan tertulis yang digunakan untuk memperoleh informasi dari responden, yang terdiri dari angket pengendalian emosi dan angket etika komunikasi. Untuk menilai jawaban siswa digunakan skala Likert sebagai berikut:

Pemberian Skor Angket Berdasarkan Skala Likert

\begin{tabular}{|c|c|l|c|l|}
\hline \multirow{2}{*}{ NO. } & \multicolumn{2}{|c|}{ Pertanyaan Positif } & \multicolumn{2}{c|}{ Pertanyaan Negatif } \\
\cline { 2 - 5 } & Skor & \multicolumn{1}{|c|}{ Keterangan } & Skor & \multicolumn{1}{|c|}{ Keterangan } \\
\hline 1. & 5 & Sangat Setuju & 1 & Sangat Setuju \\
\hline 2. & 4 & Setuju & 2 & Setuju \\
\hline 3. & 3 & Kurang Setuju & 3 & Kurang Setuju \\
\hline 4. & 2 & Tidak Setuju & 4 & Tidak Setuju \\
\hline 5 & 1 & Sangat Tidak Setuju & 5 & Sangat Tidak Setuju \\
\hline
\end{tabular}

Peneliti menggunakan analisis interval untuk mengetahui gambaran tingkat pengendalian emosi siswa SMP Swasta Silinda sebelum dan sesudah diberi perlakuan berupa bimbingan kelompok. Sehingga dapat diketahui seberapa besar bimbingan kelompok dapat meningkatkan pengendalian emosi siswa SMP Swasta Silinda. 
Untuk mendeskripsikan tingkat pengendalian emosi yang memiliki rentang skor 1-5, maka interval pengendalian emosi sbb :

Skor maksimal $\quad$ : 5 X $55 \quad: 275$

Skor minimal $\quad: 1 \times 55: 55$

Rentang : $\quad 275-55: 220$

Interval $\quad: 220: 5: 44$

\begin{tabular}{|c|c|}
\hline SKOR & KRITERIA \\
\hline $231<\mathrm{x} \leq 275$ & Sangat Tinggi \\
\hline $187<\mathrm{x} \leq 231$ & Tinggi \\
\hline $143<\mathrm{x} \leq 187$ & Sedang \\
\hline $99<\mathrm{x} \leq 143$ & Rendah \\
\hline $55<\mathrm{x} \leq 99$ & Sangat Rendah \\
\hline
\end{tabular}

\section{HASIL PENELITIAN}

\section{Data Pre-test Etika Komunikasi Siswa}

Berdasarkan data yang diperoleh dari hasil penelitian dengan jumlah responden 10 orang terdapat skor terendah $=95$ dan skor tertinggi $=112$, dengan rata-rata $(M)=101.50$ dan Standard Deviasi $(\mathrm{SD})=6.02$.

\section{Data Post-test Etika Komunikasi Siswa}

Berdasarkan data yang diperoleh dari hasil penelitian dengan jumlah responden 10 orang terdapat skor terendah 153 dan skor tertinggi 157, dengan rata-rata $(\mathrm{M})=155.50$ dan Standard Deviasi $(\mathrm{SD})=1,35$.

\section{Uji Validitas}

Berdasarkan hasil perhitungan koefisien korelasi, untuk butir angket pengendalian emosi nomor 1 diperoleh $\mathrm{r}_{\mathrm{xy}}=0,414$ pada taraf signifikan $\alpha=5 \%$ dan $\mathrm{N}=55$ didapat nilai $\mathrm{r}_{\text {tabel }}$ $=0,261$ selanjutnya dari hasil tersebut dapat dilihat bahwa $r_{x y}>r_{\text {tabel }}$ yaitu 0,414 $>0,261$. Contoh Perhitungan butir angket nomor 1 adalah sebagai berikut :

$$
\begin{gathered}
\mathrm{r}_{\mathrm{xy}}=\frac{n \sum X Y-\sum X \sum Y}{\sqrt{\left\{n \sum X^{2}-\left(\sum X\right)^{2}\right\}\left\{n \sum Y^{2}-\left(\sum Y\right)^{2}\right\}}} \\
\mathrm{r}_{\mathrm{xy}}=\frac{(55 \times 8902)-(77 \times 2849)}{\sqrt{\left\{(55 \times 247)-(77)^{2}\right\}\left\{(55 \times 329795)-(2849)^{2}\right\}}} \\
\mathrm{r}_{\mathrm{xy}}=\frac{11093}{\sqrt{717849344}} \\
\mathrm{r}_{\mathrm{xy}}=\frac{11093}{26792} \\
\mathrm{r}_{\mathrm{xy}}=0,414
\end{gathered}
$$

\section{Uji Reliabilitas}

Nilai reliabilitas etika komunikasi yang dicari dengan rumus alpha adalah sebagai berikut : 


$$
\begin{gathered}
r 11=\left[\frac{k}{k-1}\right]\left[1-\frac{\sum \sigma b^{2}}{\sigma \tau^{2}}\right] \\
r 11=\left[\frac{40}{40-1}\right]\left[1-\frac{19}{211.1}\right] \\
r 11=\left[\frac{40}{39}\right][1-0,090] \\
r 11=1,025.0,91 \\
r 11=0,932
\end{gathered}
$$

Data Pretes dan Postes Etika Komunikasi Siswa.

\begin{tabular}{|c|c|c|c|c|c|c|}
\hline No. & $\begin{array}{c}\text { Nama } \\
\text { Inisial } \\
\text { Siswa }\end{array}$ & $\begin{array}{c}\text { Pretes } \\
\left(\mathbf{X}_{\mathbf{1}}\right)\end{array}$ & $\begin{array}{c}\text { Postes } \\
\left(\mathbf{X}_{\mathbf{2}}\right)\end{array}$ & $\begin{array}{c}\text { Selisih } \\
(\mathbf{d}) \mathbf{X}_{\mathbf{1}} \\
-\mathbf{X}_{\mathbf{2}}\end{array}$ & $\begin{array}{c}\mathbf{X}_{\mathbf{d}} \\
(\mathbf{d}- \\
\mathbf{M d})\end{array}$ & $\mathbf{X}_{\mathbf{d}}$ \\
\hline 1 & R02 & 104 & 155 & 51 & -3 & 9 \\
\hline 2 & R08 & 95 & 157 & 62 & 8 & 64 \\
\hline 3 & R12 & 101 & 156 & 55 & 1 & 1 \\
\hline 4 & R17 & 96 & 154 & 58 & 4 & 16 \\
\hline 5 & R18 & 103 & 155 & 52 & -2 & 4 \\
\hline 6 & R21 & 104 & 153 & 49 & -5 & 25 \\
\hline 7 & R27 & 112 & 157 & 45 & -9 & 81 \\
\hline 8 & R42 & 96 & 155 & 59 & 5 & 25 \\
\hline 9 & R46 & 95 & 156 & 61 & 7 & 49 \\
\hline 10 & R55 & 109 & 157 & 48 & -6 & 36 \\
\hline \multicolumn{2}{|c|}{\begin{tabular}{|l} 
(Jumlah) \\
M (rata- \\
rata)
\end{tabular}} & 1015 & 1555 & 540 & & 310 \\
\hline
\end{tabular}

Dari harga-harga di atas, diperoleh :

$$
\begin{aligned}
& M d=54,00 \\
& \Sigma X^{2}{ }_{d}=310 \\
& N=10
\end{aligned}
$$

Maka,

$$
\begin{aligned}
\mathrm{t} & =\frac{M d}{\sqrt{\frac{\sum X^{2} d}{N(N-1)}}} \\
\mathrm{t} & =\frac{54,00}{\sqrt{\frac{310}{10(10-1)}}} \\
\mathrm{t} & =\frac{54,00}{1,85} \\
\mathrm{t} & =29,18
\end{aligned}
$$

dari perhitungan etika komunikasi $t_{\text {hitung }}$ nya sebesar 29.18 sedangkan pada tingkat signifikansi $5 \%$ dan $\mathrm{dk}=\mathrm{N}-1=10-1=9$ diperoleh $\mathrm{t}$ table sebesar 1,83. Karena $t_{\text {hitung }}>\mathrm{t}_{\text {tabel }}$ yaitu 29.18> 1,83 maka hipotesis yang diajukan yaitu "Ada Manfaat Bimbingan Kelompok dalam Meningkatkan Etika Komunikasi, dapat diterima dan teruji kebenarannya pada taraf signifikansi $5 \%$. 


\section{KESIMPULAN}

Berdasarkan hasil penelitian, maka dapat disimpulkan bahwa Bimbingan Kelompok bermanfaat dalam Meningkatkan Etika Komunikasi. Hal ini terlihat sebelum mendapat bimbingan kelompok etika komunikasi siswa kelas VIII SMP Swasta Silinda berada pada kategori rendah dan setelah dilakukan bimbingan kelompok etika komunikasi mereka mengalami peningkatkan pada kategori sedang.

\section{DAFTAR PUSTAKA}

Arikunto, Suharsimi, 2006. Prosedur Penelitian Suatu Pendekatan Praktik. Jakarta : Rineka Cipta.

Ary Ginajar, 2003, ESQ Power,Jakarta: Arga.

AW. Suranto. 2011. Komunikasi Interpersonal. Yogyakarta: Graha Ilmu.

Dawson dalam Triatna dan Kharisma (2008:25) Journal Formatif S(1): 26:41, 2015 ISSN: 2088-35IX.

Goleman (2015) dalan Journal Ilmiah Cisoc Vol II No.2 2016/ISSN 2460-1802.

Hartinah, Sitti. 2009. Konsep Dasar Bimbingan Kelompok Bandung: Refika Aditama.

Lahmuddin, 2006, Konsep-konsep Dasar Bimbingan dan Konseling, Bandung; Citapustaka Media.

Prayitno, Amti Erman. 2008. Dasar-dasar Bimbingan dan Konseling. Jakarta: Rineka Cipta.

Prayitno. 2012. Seri Panduan Layanan dan kegiatan Pendukung Konseling. Padang: Universitas Negeri Padang.

Santoso AS. 2008. Modul 10 Kepribadian dan Emosi. Universitas Mercu Buana.

Tohirin. 2007. Bimbingan dan Konseling di Sekolah dan Madrasah (Berbasis Integrasi). Jakarta: Raja Grafindo Persada. 